本邦における心臓血管外科手術の現状：

2015 年, 2016 年の日本心臓血管外科手術データベースの検討

\title{
2. 単独冠動脈バイパス手術
}

\author{
日本心臟血管外科手術データベース機構 \\ 齋 藤 綾*1 平 原 憲 道 ${ }^{2}$ 本 村 昇 ${ }^{1}$ 宮田 裕 章 ${ }^{2}$ 高 本 䢐 - ${ }^{2}$
}

2015 年および 2016 年の日本心臓血管外科手術データベース登録の単独冠動脈バイパス術症例について術前 状態および術後短期成績, グラフト選択の現況, 前下行枝血行再建へのグラフト選択 (年齢別) について分 析した。単独冠動脈バイパス術については $55.0 \%(29,395$ 例中 16,173 例）に人工心肺が使用された。左前下 行枝の血行再建には LITA が 72.1\% (29,392 例中 21,217 例)，RITA が 17.4\% に使用され前回の報告から微 増した。手術死亡率は待機的手術では 1.7\% (On-pump CABG : ONCAB 2.5\%, off-pump CABG : OPCAB $1.1 \%, p<0.001)$ ，緊急手術では 8.8\%（ONCAB 12.9\%，OPCAB 4.0\%, p<0.001），全体では 3.0\%であり， その他合併症も含め OPCAB で有意に成績が良好であった。（*手術死亡率：術後 30 日以内の死亡または在 院中の死亡.）日心外会誌 48 巻 1 号 : 6-10（2019）

キーワード：冠動脈バイパス術；グラフト選択；人工心肺非補助下冠動脈バイパス術；人工心肺補助下 冠動脈バイパス術

Current Status of Cardiovascular Surgery in Japan : Analysis of Data from Japan Cardiovascular Surgery Database in 2015, 2016. 2. Isolated Coronary Artery Bypass Surgery

Aya Saito ${ }^{1}$, Norimichi Hirahara ${ }^{2}$, Noboru Motomura ${ }^{1}$, Hiroaki Miyata ${ }^{2}$ and Shinichi Takamoto $^{2}$ (Department of Cardiovascular Surgery, Toho University Sakura Medical Center ${ }^{1}$, Sakura, Japan, and Department of Health Policy and Management, School of Medicine, Keio University ${ }^{2}$, Tokyo, Japan) We reviewed the data of the isolated coronary artery bypass grafting (CABG) procedures performed in 2015 and 2016, as registered in the Japan Cardiovascular Surgery Database, for preoperative characteristics, surgical outcomes, and the choice of graft material used for the left anterior descending artery (LAD). Isolated CABG was performed off-pump in 55.0\% $(n=16,173)$ of all CABG cases $(n=29,392)$. The left internal thoracic artery and the right internal thoracic artery were used as the graft materials in 72.1 and $17.4 \%$ cases respectively. The operative mortality rates remained unchanged since the last report, with $1.7 \%$ for elective cases, $8.8 \%$ for emergency cases, and $3.0 \%$ overall. In elective cases, the operative mortality rate was $1.1 \%$ for off-pump CABG (OPCAB) compared with $2.5 \%$ for on-pump CABG. The morbidity rates for all OPCAB cases were significantly better except for those falling in the 'readmission <30 days' group. Jpn. J. Cardiovasc. Surg. 48:6-10 (2019)

Keywords : coronary artery bypass grafting; graft choice; off-pump coronary artery bypass grafting ; on-pump coronary artery bypass grafting

\section{緒言}

冠動脈バイパス術は開心術の中では依然として最も多い 件数を占めるが, 経皮的カテーテル治療（PCI）の躍進に より手術症例は近年減少し, 症例に再配分 - 重症化する傾
向が認められている．確実な手術成績を得るうえではわれ われの治療成績および術式詳細に関する情報を共有するこ とが重要である。

この報告では 2015 年, 2016 年の日本心臓血管外科手術 データベース（JCVSD）を基に，術後短期成績やグラフ

\footnotetext{
2018 年 11 月 7 日受付

* Corresponding author : Aya Saito

The Japan Cardiovascular Surgery Database (JCVSD), the Japanese Society for Cardiovascular Surgery, Tokyo, Japan Email : ayasaitou-ths@umin.ac.jp

*日本心臓血管外科手術データベース機構

干 113-0033 東京都文京区本郷 2-26-9 鈴木ビル 6F 日本心 臓血管外科学会内
}

\author{
${ }^{1}$ 東邦大学医療センター佐倉病院心臓血管外科 \\ 2 慶應義塾大学医学部医療政策・管理学
}

本研究において一切の利益相反や研究資金の提供はない.

None of the authors of this manuscript has any financial or personal relationship with other people or organizations that could inappropriately influence their work. 
トの使用状況に関する詳細なデータをまとめ，2013 年と 2014 年のデータ ${ }^{1)}$ との比較を含めて報告する.

\section{対象および方法}

2015 年 1 月〜 2016 年 12 月に本邦で行われた単独冠動脈 バイパス術をJCVSD 登録症例より抽出し対象とした。症 例の抽出方法は冠動脈バイパス術（併設手術なし）とし た。術前並存疾患，使用グラフトの種類すなわち片側内胸 動脈 (single internal thoracic artery: SITA), 両側内胸動 脈 (bilateral internal thoracic artery: BITA), 右胃大網動 脈 (right gastroepiploic artery: GEA), radial artery: RA, saphenous vein graft : SVG) の使用頻度扎よび左前下行枝 (left anterior descending artery: LAD) へ吻合するグラフ 卜選択について年齢別に集計した。術後短期成績について は全体および人工心肺使用 (On-pump CABG : ONCAB) / 非使用症例（Off-pump CABG：OPCAB）に分けて集計し, $\mathrm{ONCAB}$ と OPCAB での成績比較を待機・緊急扎よび準緊 急手術ごとに行った。脂質異常症の定義は高 LDL 血症 (空腹時 $\mathrm{LDL} 140 \mathrm{mg} / \mathrm{dl}$ 以上), 低 HDL 血症 (HDL 40 $\mathrm{mg} / \mathrm{dl}$ 未満) または高トリグリセライド血症（TG 150 $\mathrm{mg} / \mathrm{dl}$ 以上）のいずれかを満たす場合，腎機能障害は蛋白 尿の存在, 血清クレアチニン值 $1.3 \mathrm{mg} / \mathrm{d} 1$ 以上，または eGFR $60 \mathrm{ml} / \mathrm{min} / 1.73 \mathrm{~m}^{2}$ 以下のいずれかを満たす場合, 慢性呼吸障害は肺機能 1 秒率 $75 \%$ 以下もしくは気管支拡 張薬の吸入もしくは内服, 呼吸器疾患に対するステロイド 使用, Room Air にて $\mathrm{PO}_{2}<60$ もしくは $\mathrm{PCO}_{2}>50$ とした。 2 群の比較は $\chi^{2}$ 検定により行い, $p<0.05$ を有意とした。

\section{結果}

Table 1 では術前患者状態について示した。症例総数が 2 年間で 29,395 例， $2013 ， 2014$ 年の 2 年間の症例数 (31,987 例) と比べ 2,592 例も減少していた。術前状態に おける年次変化はほぼ認めなかった。

Table 2 にはグラフト選択状況（組み合わせ）について 特に ITA 使用状況打よび動脈グラフトのみ使用の場合の パターンに着目して示した. Table 2-1には定時手術にお けるグラフト選択の詳細を示した。年齢別症例数は前回報 告と比べやや高齢者への配分が増加し, 70 歳以上の症例 が全体の $50.5 \%(n=12,309)$ を占めた（前回報告では $45.4 \%(n=12,548)) .60$ 歳未満の症例は SITA $(n=$ $1,908)$, BITA $(n=1,895)$ でほぼ同数であった. 60 歳以 上の症例では SITA $(n=12,095)$, BITA $(n=7,323)$ であ り (SITA/BITA ratio 1.65)，60 歳以上では前報告に比べる と BITA 使用頻度が増加した（前報告 SITA $n=13,208$, BITA $n=7,473$, SITA/BITA ratio 1.77). 全年齢層でみた 場合の動脈グラフトのみの使用頻度は前報告に比べ
Table 1 Preoperative patients' characteristics

\begin{tabular}{lrr}
\hline & \multicolumn{1}{c}{$n$} & \multicolumn{1}{c}{$\%$} \\
\hline Male & 23,252 & 79.1 \\
Obese & 6,685 & 22.7 \\
Smoking & 15,117 & 51.4 \\
Family history & 2,777 & 9.4 \\
Diabetes & 15,811 & 53.8 \\
Dyslipidemia & 18,626 & 63.4 \\
Hypertention & 22,708 & 77.3 \\
COPD & 4,288 & 14.6 \\
Cerebrovascular disease & 3,478 & 11.8 \\
Renal insufficiency & 8,431 & 28.7 \\
Hemodialysis & 3,205 & 10.9 \\
Arrhythmia (Af/AF) & 1,473 & 5.0 \\
Extracardiac arteriopathy & 5,048 & 17.2 \\
Surgery on PAD/AAA & 1,326 & 4.5 \\
NYHA III. IV & 6,193 & 21.1 \\
OMI & 7,258 & 24.7 \\
AMI & 3,904 & 13.3 \\
Unstable angina & 9,828 & 33.4 \\
History of PCI & 7,379 & 25.1 \\
Stent thrombosis & 475 & 1.6 \\
Indication of CABG in relation to PCI & & \\
PCI complication & 423 & 1.4 \\
PCI failure w/o clinical deterioration & 872 & 3.0 \\
PCI/CABG hybrid procedure & 685 & 2.3 \\
Clinical other than above & 27,415 & 93.3 \\
\hline
\end{tabular}

SITA・BITA 使用例にて顕著に増加した（前回報告 : SITA 群動脈の及使用 $n=2,668$. 全 SITA 使用症例の $17.5 \%$, BITA 群 $n=3,202$, 全 BITA 使用症例の $32.9 \%$, 今回報告 : SITA 群動脈の及使用 $n=2,740,19.6 \%$, BITA 群 : $n=3,319,36.0 \%)$. Table 2-2 には緊急/準緊急症例に打け るグラフト選択について示した。予定手術に比べ BITAの 使用割合は減っていたが (予定/緊急・準緊急 37.8\%/ $25.5 \%)$, SITA に比べ BITA の使用頻度は前回報告と比べ 全年齢層において増加傾向を認めた。

Table 3 には LAD への血行再建に用いたグラフトの分布 を年齢別に示した。 LITAの使用頻度は $76.2 \%$, RITA は $18.4 \%$ ，特に若年層での使用が多かった. SVG (5.0\%), RA (0.5\%)，GEA (0.1\%) の使用頻度は前回報告と同様に非常 に限られた症例に対してのみ選択されていた。

Table 4 では術後短期成績について全体像打よび予定手 術/緊急・準緊急手術に分け合併症ごとの発症率を調べた。 さらに ONCAB と OPCAB の発生頻度の差を集計した。 $2015 \sim 2016$ 年の $\mathrm{OPCAB}$ 症例数は, 全単独 $\mathrm{CABG}$ 手術の うち 55.0\%（OPCAB/total CABG 16,173/29,395）を占め例 年どおりであった。全体を通しては出血 (1.7\%), 脳梗塞 (1.7\%), 縦隔炎 $(1.5 \%)$, 腎機能障害 $(3.4 \%), 72$ 時間を超 える人工呼吸管理 $(5.2 \%)$, 肺炎 $(2.5 \%)$, 消化管障害 (1.2\%)，心房細動 (12.4\%) とわずかに減少したが，手術 

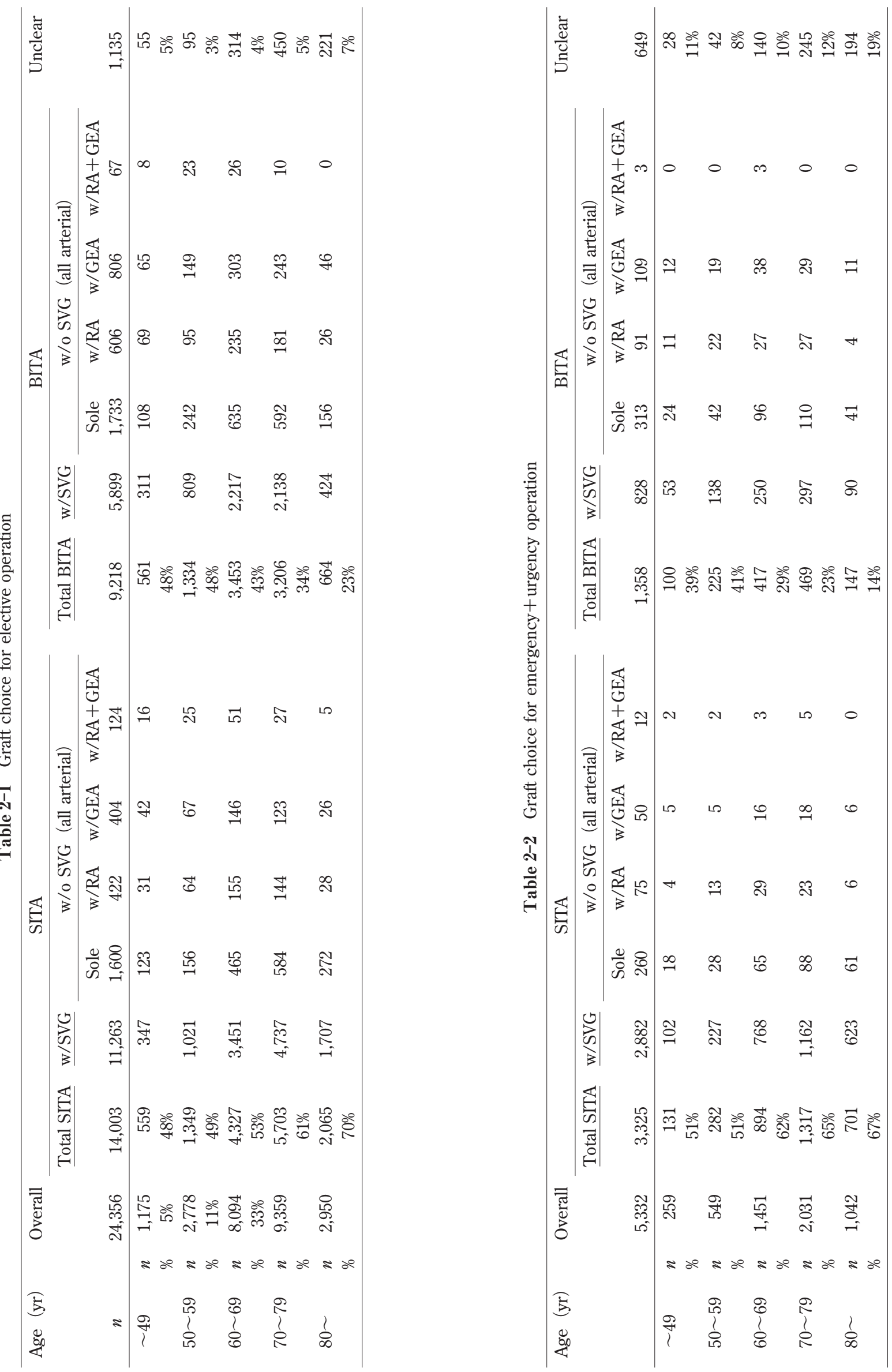
Table 3 Graft selection for $\mathrm{LAD}$ revascularization

\begin{tabular}{ccccccc}
\hline & LITA & RITA & RA & GEA & SVG & \\
& $n=21,217$ & $n=5,127$ & $n=139$ & $n=22$ & $n=1,381$ & $n=27,886$ \\
Age & $76.1 \%$ & $18.4 \%$ & $0.5 \%$ & $0.1 \%$ & $5.0 \%$ & $100.0 \%$ \\
\hline$\sim 50$ & 1,010 & 279 & 6 & 0 & 43 & 1,338 \\
& $75.5 \%$ & $20.9 \%$ & $0.4 \%$ & $0.0 \%$ & $3.2 \%$ & $100.0 \%$ \\
\hline $50 \sim 59$ & 2,335 & 669 & 19 & 3 & 87 & 3,113 \\
& $75.0 \%$ & $21.5 \%$ & $0.6 \%$ & $0.1 \%$ & $2.8 \%$ & $100.0 \%$ \\
\hline $60 \sim 69$ & 6,722 & 1,890 & 48 & 11 & 339 & 9,010 \\
& $74.6 \%$ & $21.0 \%$ & $0.5 \%$ & $0.1 \%$ & $3.8 \%$ & $100.0 \%$ \\
\hline $70 \sim 79$ & 8,210 & 1,856 & 50 & 7 & 547 & 10,670 \\
& $76.9 \%$ & $17.4 \%$ & $0.5 \%$ & $0.1 \%$ & $5.1 \%$ & $100.0 \%$ \\
\hline $80 \sim$ & 2,940 & 433 & 16 & 1 & 365 & 3,755 \\
& $78.3 \%$ & $11.5 \%$ & $0.4 \%$ & $0.0 \%$ & $9.7 \%$ & $100.0 \%$ \\
\hline
\end{tabular}

死亡率 3.0\% と前回同様の結果であった．待機手術と緊急/ 準緊急手術を比べた場合の合併症併発率はすべてにおいて 後者で有意に高く，手術死亡率も待機手術で $1.7 \%$ ，緊急/ 準緊急手術で $8.8 \%$ と後者で有意に高かった。ONCAB と OPCAB の成績では全般的に OPCAB が良好で待機手術の 手術死亡率では OPCAB/ONCAB 1.1\%/2.5\%，緊急/準緊急 手術 OPCAB/ONCAB 4.0\%/12.9\%であった（Table 4，い ずれも $p<0.001)$.

\section{考察}

The Society of Thoracic Surgeons National Database によ る Executive summaries の中では Adult Cardiac Surgery Database を基に手技別に年次症例数，死亡率が報告され ている．年間約 10 万件の症例が登録されているが， 2017 年に報告された STS annual report 2016 年の成績では ${ }^{2}$ 単 独 CABG の in-hospital/Operative death は 1.8/2.2\% であり 今回のわれわれの 2015,2016 年データから得られた overall operative mortality 3.0\% より死亡率は低かった。ちなみ にSTS の報告で in-hospital mortality が operative mortality を下回るという結果は日本医療では観察されない事象であ る. 米国では手術入院期間が短く後者は退院後の死亡も含 まれており，各国の医療制度に起因する死亡率の計上方法 の違いが結果に反映されたと考えられる。また，術後の合 併症発症状況は縦隔炎については，わが国での発症状況 （1.5\%）は STS からの報告（0.3\%）と比べ依然として高く, また前回の JCVSD biannual report からの報告 $(1.8 \%)$ と 比べると軽度低下傾向にあった。 BITA 使用が増加傾向に ある状況を加味すると胸部正中創の管理，血糖值管理を含 めた全身管理状況が縱隔炎発症予防に影響した可能性など も考えられた。心房細動発症についてはSTS 報告では $24.0 \%$ と高く，わが国の $12.4 \%$ を大く上回っていた。各 国の医療情勢の違いが短期手術成績に影響を及ぼしている
可能性が十分考えられるため, 本邦における心臟血管外科 の現状（入院期間，手術死亡時期など）についても観察さ れることが必要かもしれない。

グラフト選択については RITA の使用が増加傾向にあっ た．特に緊急症例における BITA 使用が増加傾向にあるこ と, LAD への血行再建に RITA が使用されることが増加 していることなどが顕著であった。 BITA 使用の有用性に ついては賛否両論が多く議論の余地を残すところであ $り^{3,4)}$ ，過去の報告打よび今回得られた結果の解釈打よび 突合は慎重に行う必要がある。

ONCAB と OPCAB に打ける術後の合併症併発状況は, 緊急性を問わず再入院以外 OPCAB で有意に低く, deep sternal infection については予定手術にて OPCAB での発 症率が有意に低かった。Isolated CABG のうち OPCAB の 占める割合は 10 年ほど安定しており 2015 年では $62.8 \%$ と 報告されていた ${ }^{5}$. 今回のわれわれの報告では $\mathrm{OPCAB}$ 施 行率は 55.0\%（OPCAB 16,173 例/全 isolated CABG 29,395 例）に留まりわれわれの前回の報告 $(54.7 \%)$ と比べほぼ 横ばいであった ${ }^{1)}$. 日本胸部外科学会学術委員会からの 2015 年の年次報告では $\mathrm{CABG}$ 手術件数は 2014 年 ${ }^{6}$ に比心゙ $4.3 \%$ 減少しており，われわれの報告と同様 OPCAB 施行率 は今後も引き続き横ばい〜減少傾向になることが見込まれ る。な打，日本胸部外科学会からの年次報告はアンケート 調査結果に由来する集計であり，JCVSD のレジストリー に基づく集計と数值には多少の差が生じるのが現状であ る．全症例に対する OPCAB が占める割合および患者背景 や重症度については，わが国に打ける PCI 施行状況と連 動することが予想されるため，PCI に緾わる臨床の現状に ついて全国レベルでのレジストリー報告が待たれるところ である。ちなみに 2016 年度に公表された循環器疾患診療 実態調査報告書（the Japanese Registry Of All cardiac and vascular Disease : JROAD）によると待機的 PCI，緊急 PCI 


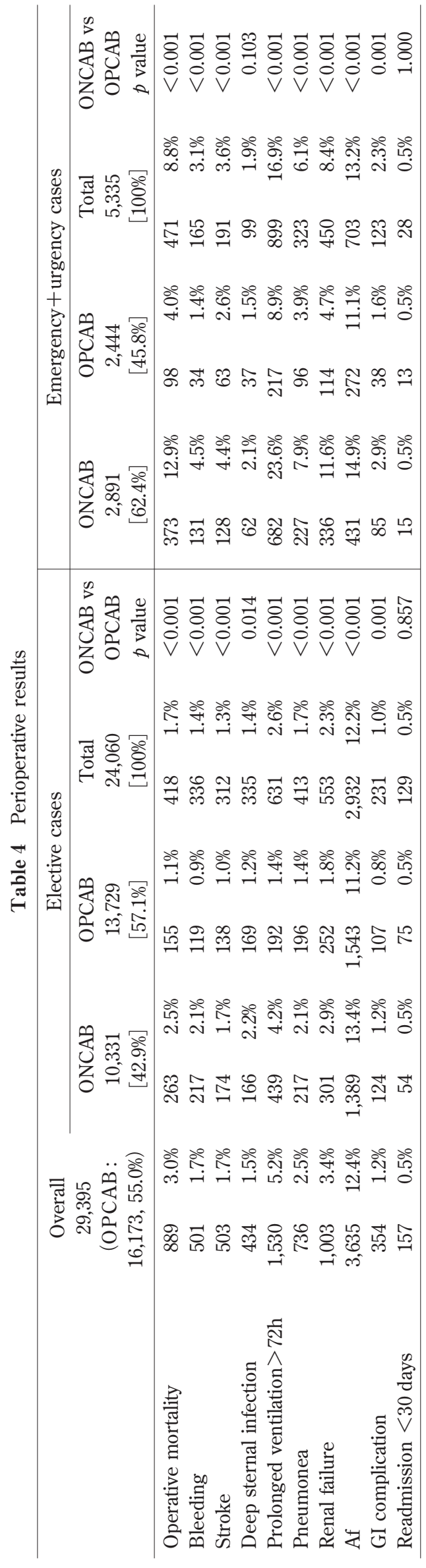

ともに 2016 年にかけて年次ごとに微増しており，2016 年 の実績では前者が 192,774 件, 後者で 71,799 件と報告され ている.

諸外国，特に STS 年次報告と術後成績を単純に比較す ることは困難である。たとえば，医療保険制度の差異に伴 い平均入院期間が日米で異なることが想定されるが，たと えば縦隔炎について発症が手術と同一入院期間に確認され るか, 発覚前に退院となり再入院として確認されるかに よって合併症の算定基準が異なり「outcome shift」が生じ うる. 合併症発症率については, 項目ごとに地域別の医療 事情を加味し評価することは困難であり, 結論の意味付け には注意を要する。

\section{結 語}

2015，2016 年における本邦での単独 CABG 手術症例を 対象に，グラフト選択の詳細打よび人工心肺使用の有無に 着目した術後成績についてまとめた。動脈グラフトの特に 両側 ITA を沉用する傾向が認められた。また，OPCABに おいて手術死亡率を含む術後短期成績が有意に良好であっ た．詳細にわたるデータについて今後も解析を重ね, 手術 手技の改良执よび手術成績の向上に貢献できることが期待 される。

\section{文献}

1) Saito $\mathrm{A}$, Hirahara $\mathrm{N}$, Motomura, $\mathrm{N}$ et al. Current status of cardiovascular surgery in Japan, 2013 and 2014 : a report based on the Japan Cardiovascular Surgery Database (JCVSD) 3. Coronary artery bypass surgery. Jpn J Cardiovasc Surg $2017 ; 46: 195-8$.

2) Jacobs JP, Shahian DM, D'Agostino RS et al. The society of thoracic surgeons national database 2017 annual report. Ann Thorac Surg $2017 ; 104: 1774-81$.

3) Buttar SN, Yan TD, Taggart DP et al. Long-term and shortterm outcome of using bilateral internal mammary artery grafting versus left internal mammary artery grafting: a meta-analysis. Heart 2017;103:1419-26. doi : 10.1136/ heartjnl-2016-310864 (Epub 2017 June 23)

4) Janiec M, Dimberg A, Shafti TZN et al. No improvements in long-term outcome after coronary artery bypass grafting with arterial grafts as a second conduit: a Swedish nationwide registry study. Eur J Cardio-Thorac Surg 2018; 53 : 448-54.

5) Masuda M, Endo S, Natsugoe $S$ et al. ; Committee for Scientific Affairs, the Japanese Association for Thoracic Surgery.Thoracic and cardiovascular surgery in Japan during 2015. Gen Thorac Cardiovasc Surg 2018; 10 : 581-615. Doi : 10.1007/s11748-018-0968-0 (Epub ahead of print)

6) Masuda M, Okumura M, Doki $Y$ et al.; Committee for Scientific Affairs, the Japanese Association for Thoracic Surgery. Thoracic and cardiovascular surgery in Japan during 2014. Gen Thorac Cardiovasc Surg 2016 ; 64 : 66597. 